Hydrology and Earth System Sciences, 8(5), 877-890 (2004) C EGU

\title{
Snowmelt runoff from northern alpine tundra hillslopes: major processes and methods of simulation
}

\author{
W.L. Quinton ${ }^{1}$, S.K. Carey ${ }^{2}$ and N.T. Goeller ${ }^{1}$ \\ ${ }^{1}$ Dept. of Geography, Simon Fraser University, Burnaby, British Columbia, V5A 1S6, Canada \\ ${ }^{2}$ Dept. of Geography, University of Saskatchewan, Saskatoon, Saskatchewan, S7N 5A5, Canada \\ Email for corresponding author: bquinton@sfu.ca
}

\begin{abstract}
In northern alpine tundra, large slope gradients, late-lying snow drifts and shallow soils overlying impermeable substrates all contribute to large hillslope runoff volumes during the spring freshet. Understanding the processes and pathways of hillslope runoff in this environment is, therefore, critical to understanding the water cycle within northern alpine tundra ecosystems. This study: (a) presents the results of a field study on runoff from a sub-alpine tundra hillslope with a large snow drift during the spring melt period; (b) identifies the major runoff processes that must be represented in simulations of snowmelt runoff from sub-alpine tundra hillslopes; (c) describes how these processes can be represented in a numerical simulation model; and d) compares field measurements with modelled output to validate or refute the conceptual understanding of runoff generation embodied in the process simulations. The study was conducted at Granger Creek catchment, $15 \mathrm{~km}$ south of Whitehorse, Yukon Territory, Canada, on a north-facing slope below a late-lying snow drift. For the freshet period, the major processes to be represented in a runoff model include the rate of meltwater release from the late-lying snowdrift, the elevation and thickness of the saturated layer, the magnitude of the soil permeability and its variation with depth. The daily cycle of net all-wave radiation was observed to drive the diurnal pulses of melt water from the drift; this, in turn, was found to control the daily pulses of flow through the hillslope subsurface and in the stream channel. The computed rate of frost table lowering fell within the observed values; however, there was wide variation among the measured frost table depths. Spatial variability in frost table depth would result in spatial variabilities in saturated layer depth and thickness, which would, in turn, produce variations in subsurface flow rates over the slope, including preferential flowpaths.
\end{abstract}

Keywords: subsurface runoff, alpine tundra, permafrost, organic soils, model simulation

\section{Introduction}

Knowledge of hydrological pathways and processes that control the movement of water (including nutrients, sediment and biota) is essential to understanding the functioning of alpine tundra ecosystems, and how they might change with changes in energy and water availability. In alpine tundra environments of sub-arctic North America, the overall runoff pathway to the basin outlet extends from the surface of the melting snowpack, includes vertical percolation through the snowpack, horizontal drainage across the hillslope, and finally flow through the stream channel. The overall travel time to the basin outlet is, therefore, controlled by the ability of these major flowpath components to convey moisture.

During winter, movement of water in the alpine tundra is dominated by wind transport of snow (Pomeroy et al., 1993, 1995, 1997; Essery et al., 1999). By late winter, there are extensive areas of exposed, sparsely vegetated tundra with a relatively thin snow cover, and small areas, such as stream channels and hillsides where the snow may be several metres deep (Pomeroy et al., 1993). During the two to three week snowmelt runoff period, eight or nine months of accumulated precipitation is released. The occurrence of late-lying snowdrifts, whose placement and size are controlled by a combination of atmospheric and landform factors (Sturm et al., 1998) has a large influence on streamflow in permafrost environments (Marsh and Woo, 1981; Woo and Steer, 1983; Lewkowicz and Young, 1990). The melting snowdrifts result in high flows continuing after the principal snowmelt period. Beneath the snow lies the surface of the tundra, the treeless 
terrain with a continuous organic cover (NRC, 1988), which occupies one-third of the Canadian Arctic (Bliss and Matveyeva, 1992). Hydrological studies in the tundra region have reported an overall organic thickness of $0.2-0.5 \mathrm{~m}$ (e.g. Slaughter and Kane, 1979; Roulet and Woo, 1988; Hinzman et al., 1993); with lower thickness (0.1-0.3 m) reported in regions of higher latitude (Quinton and Marsh, 1999) and altitude (Carey and Woo, 2001). However, regardless of the location, tundra soils are typically composed of a highly permeable 0.1 to $0.25 \mathrm{~m}$ upper layer of living and lightly decomposed vegetation, overlying a more decomposed, less permeable layer (Quinton and Gray, 2003).

Drainage processes in organic-covered terrains are distinct from those of other permafrost areas. For example, little or no surface flow is experienced, due to the large water holding capacity of organic soils (Slaughter and Kane, 1979; Quinton and Marsh, 1999) and high frozen and unfrozen infiltration rates (Dingman, 1973; Quinton et al., 2000), which far exceed the rate of input from snowmelt or rainfall. Melt water can percolate through the unsaturated, highly porous organic soil and move rapidly downslope (Quinton and Marsh, 1999, Carey and Woo, 2001), even while the ground is still snow-covered (Quinton and Marsh, 1998), and before the moisture deficit of the soil is satisfied (Chacho and Bredthauer, 1983).

The increasing degree of decomposition with depth below the ground surface results in depth-variations of soil properties. For example, the proportion of small, closed and dead-end pores, and the amount of dry material per unit volume increases with depth (Verry and Boelter, 1978; Quinton et al., 2000). Saturated hydraulic conductivity has been found to decrease by two to three orders of magnitude over a $0.2 \mathrm{~m}$ increase in depth (Quinton et al., 2000). Correct delineation of subsurface lateral flow from organic-covered hillslopes therefore requires a reliable method for estimating: (1) the permeability as a function of the depth within the saturated layer, and (2) the elevation of the saturated layer, since the depth to which the saturated layer extends is limited by the relatively impermeable frost table that descends with time during soil thawing.

Quinton et al. (2000) used the Darcy-Weisback expression to define the permeability of the soil in the saturated layer as $K=2 D^{2} / C$, where $\mathrm{D}$ is the geometric mean pore diameter and $C$ is a coefficient. This suggests that $K$ can be computed directly provided the values of $C$ and $D$ are known. Field measurements indicate that during soil thawing, the coefficient $C$ increases linearly with depth to the middle of the saturated zone, $d$ (Quinton and Gray, 2001), suggesting that if $\mathrm{D}$ is known from laboratory analysis of soil cores, a $C-d$ relationship can be used to estimate the variation of $K$ with depth.
Estimating the elevation of the saturated layer requires a ground heat transfer formulation (Carey and Woo, 2000a; Quinton and Gray, 2001). Physically-based thermal transfer models involve rigorous one-dimensional solutions of heat conduction and thermodynamics (e.g. Zhao and Gray, 1999), a drawback of which is the large data requirement and substantial parameterisation. Assuming conduction is the primary flux governing the thaw of the active layer (Woo and Xia, 1994), it is reasonable to expect that a temperaturebased model will provide reasonable estimates of soil thaw.

Previous energy balance studies in arctic tundra have shown a strong association between cumulative degree day air temperature and cumulative ground heat flux (Abbey, 1978; Hinkel and Nicholas, 1995) and between cumulative values of degree-day air temperature and the portion of the ground heat flux used to melt ice in the active layer (Quinton and Gray, 2001), suggesting that temperature index models provide reasonable estimates of frost table elevation. Surface temperature has been used as an index (Quinton and Gray, 2003) rather than air temperature since the former is influenced directly by energy exchanges occurring at the ground surface and within the active layer, and offers the prospect of using remotely sensed, thermal infrared data as a method of obtaining the input variable for a thermal algorithm.

\section{Study site}

The study was conducted at Granger Creek $\left(60^{\circ} 32^{\prime} \mathrm{N}\right.$, $\left.135^{\circ} 18^{\prime} \mathrm{W}\right)$, located within the Wolf Creek Research Basin, $15 \mathrm{~km}$ south of Whitehorse, Yukon Territory, Canada. The study area has a sub-arctic continental climate characterised by a large temperature range and low precipitation. Mean annual January and July temperatures from the Whitehorse airport (elevation $706 \mathrm{~m}$ a.s.1.) are $-17.7^{\circ} \mathrm{C}$ and $+14.1^{\circ} \mathrm{C}$. Mean annual precipitation is $267.4 \mathrm{~mm}$, of which $122 \mathrm{~mm}$ falls as snow (1971-2000), yet precipitation at the Whitehorse airport may underestimate basin precipitation by 25 to $35 \%$ (Pomeroy and Granger, 1999). Granger Basin drains a $6 \mathrm{~km}^{2}$ area and ranges in elevation from $1310 \mathrm{~m}$ to $2250 \mathrm{~m}$. The main river valley trends west to east at lower elevations, resulting in predominantly north- and southfacing slopes. Permafrost is found under much of the northfacing slopes and at higher elevations, whereas seasonal frost predominates on southerly exposures.

Throughout the basin, soils are composed of an organic layer of 0.1 to $0.4 \mathrm{~m}$ in thickness that contains peat and supports lichens, mosses, sedges and grasses. Willow and birch shrubs, 2-3 $\mathrm{m}$ in height, occupy much of the channel and riparian zones. They also extend upslope but decrease in density and height. In the mid-slope region, the shrubs 
are waist height and scattered and, at the upper slope, only occasional patches of short $(<0.5 \mathrm{~m})$ shrubs occur. A few scattered white spruce (Picea glauca) occur within the basin, which is considered to be above the treeline.

Snowmelt runoff was studied near the outlet of Granger Creek on a north-facing slope with an average gradient of 0.35 and underlain by permafrost. The length of the slope from its crest to the streambank is approximately $150 \mathrm{~m}$. Each year, a deep ( $>2 \mathrm{~m}$ ) snow drift forms on the upper part of the slope and persists for three to four weeks after the disappearance of the surrounding snow cover. Snow survey transects extending from the stream channel to the top of the slope indicate that at the height of snow accumulation, the drift contained $65 \%$ of the entire snow water equivalent along the transect. The average thickness of the organic layer on this slope is $0.26 \mathrm{~m}, \pm 0.10 \mathrm{~m}(\mathrm{~N}=30)$. Underlying the organic layer is sandy glacial till. The active layer ranges from approximately $0.4 \mathrm{~m}$ on the slope crest to $>1 \mathrm{~m}$ near the slope base.

To assist with the interpretation of results, the hillslope was conceptualised as containing two types of hydrological response units (HRUs): snow drift and tundra (Fig. 1). The tundra HRU extended the $70 \mathrm{~m}$ distance from the downslope edge of the snowdrift to the stream bank. To represent different slope positions, the tundra HRU was divided into sub-HRUs. Meltwater from the drift is assumed to enter the hillslope at HRU 2, flow downslope through successive HRUs, and finally enter the stream channel from HRU 8. All HRUs depicted in Fig. 1 have a width of $1 \mathrm{~m}$ for the purpose of expressing unit discharge per HRU.

\section{Methodology}

Most measurements were made during the snowmelt period of 2002, however additional measurements were made at this study site between 2000 and 2003 to gain insight into specific processes. In this section, the field methodology is presented chronologically.

At a meteorological tower near the downslope edge of the drift, ground surface temperature, air temperature and net all-wave radiation $\left(\mathrm{Q}^{*}\right)$ were measured throughout the study. Ground surface temperature was measured with a downward-looking infra-red sensor (Apogee Instruments) placed $2 \mathrm{~m}$ above the ground surface, air temperature was measured using an HMP45CF (Vaisala) at a height of $1.5 \mathrm{~m}$, and $\mathrm{Q}^{*}$ was measured at $2 \mathrm{~m}$ above the ground with a REBS Q7 net radiometer. These measurements were made every minute and averaged and recorded on a Campbell Scientific CR10X datalogger every half-hour. The accumulated rainfall was measured with a tipping bucket rain gauge (Texas Instruments) every half-hour.

In 2000, two tracer tests (Quinton et al. 2000) were conducted on a $5 \mathrm{~m} \times 5 \mathrm{~m}$ study plot to determine the horizontal hydraulic conductivity of the thawed portion of the saturated layer, through which subsurface drainage is conducted from the hillslope. The first test was conducted in early June while the snow drift was the only snow remaining on the landscape. At this time, the study plot was approximately $5 \mathrm{~m}$ downslope of the edge of the snow drift. The tracer test was repeated in September of the same year

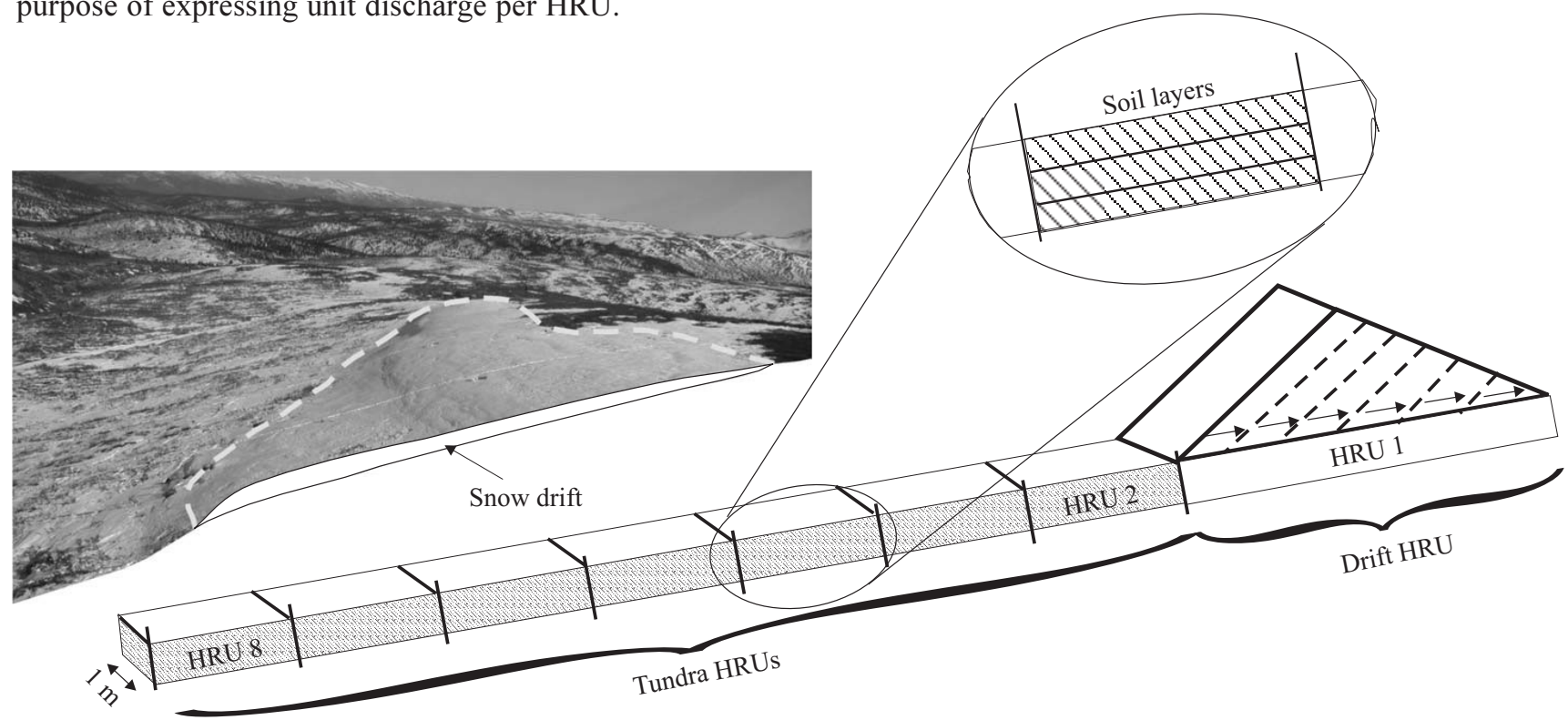

Fig. 1. Conceptual view of the hillslope under study. The photograph shows an aerial view across the crest of the hillslope that is covered by a late-lying snowdrift. The drift constitutes a single hydrological response unit (HRU). The $70 \mathrm{~m}$ distance between downslope edge of the drift and the stream bank is divided into $7 \mathrm{HRUs}$ each of $10 \mathrm{~m}$ length. Together the HRUs represent a $1 \mathrm{~m}$ wide strip extending from the drift (HRU 1) down to the stream bank (HRU 8). 
when the saturated layer was near the bottom of the organic soil and included the mineral substrate. It is assumed that the June and September tracer tests provided estimates of the upper and lower ranges of the hydraulic conductivity at the study site. A pressure transducer (Druck PDCR 950) was installed in well 1 near the meteorological tower to measure the elevation of the water table throughout the snow-free period of 2000.

In July, 2001, a soil pit was excavated next to the plot used for the tracer tests and about $10 \mathrm{~m}$ downslope of the meteorological tower. Calibrated volumetric soil moisture (CS615, Campbell Scientific) and soil temperature (107, Campbell Scientific) sensors were installed at 0.02, 0.05, $0.075,0.10,0.15,0.20,0.30,0.40$ and $0.50 \mathrm{~m}$ depths below the ground surface. The upper and lower organic layers in the soil pit were $0.24 \mathrm{~m}$ and $0.10 \mathrm{~m}$ thick respectively, giving a total organic thickness of $0.34 \mathrm{~m}$. Only the lower two sensors were in the underlying mineral sediment. The elevation of the water table was monitored continuously in a stilling well (well 2) at the soil pit with a Druck PDCR 950.

In 2002, snow depth and density measurements commenced prior to melt on 30 April and continued until 12 June using a Mount Rose snow sampling tube along three parallel transects, spaced $50 \mathrm{~m}$ apart, and each extending between the downslope and upslope edges of the snow drift. Snow density was also measured from volumetric samples taken at $0.1 \mathrm{~m}$ depth increments from snow pits. Three snow pits were excavated, one next to each transect line, roughly mid-way between the upper and lower edges of the drift, where the snow depth was roughly $2 \mathrm{~m}$. The pits, excavated on 30 April, were left open and the snow density measurements were repeated every four days. After each measurement, the pits were covered with a reflective blanket to protect them from direct solar radiation. The snow pits were also used to measure the volume of meltwater percolate that collected at the base of the snow pack. A $0.25 \mathrm{~m}^{2}$ snow melt lysimeter (Marsh and Pomeroy, 1999) was inserted into the south face at the base of the pack in each snow pit. The meltwater entering the lysimeters drained through rubber tubing into a $25 \mathrm{~L}$ reservoir. The volume of meltwater accumulated in the reservoirs was measured daily.

Daily photographs were taken of the snow drift throughout the ablation period of 2002, from the opposite hillside, to document the decrease in the surface area of the drift. The dimensions of the drift were measured weekly so that a scale could be applied to the photographs. PCI software was used to orthorectify the images, and to compute the area of the drift for each image.

The depth of the frost table below the ground surface was measured daily in 2002 from the time the surface became snow-free until mid-June, using a graduated steel rod at five fixed points on the hillslope. Two of these points were in the upper portion of the slope, within $10 \mathrm{~m}$ of the downslope edge of the snow drift, while the remaining three points were on the lower portion of the hillslope. The position of the frost table was also estimated from the elevation of the $0^{\circ} \mathrm{C}$ isotherm at the soil pit.

Three vertical soil cores $(0.4 \mathrm{~m} \times 0.1 \mathrm{~m}$ i.d. $)$ containing the entire thickness of the peat layer were extracted next to the soil pit. Sub-samples were taken from the soil cores at depths corresponding to the moisture and temperature measurements, so that the bulk density and total porosity could be measured for these depth positions. Four additional soil cores of the same dimension were sampled horizontally at $0.05,0.1,0.2$ and $0.3 \mathrm{~m}$ depths from the face of an adjacent soil pit. From these cores, drainable porosity was measured following the approach of Fuchs (1986).

In August, 2002, a snow melt lysimeter of the same dimensions to those used in the snow pits was mounted on a tipping bucket mechanism in the upper region of the hillslope, where the snow drift forms, to obtain a continuous record of meltwater infiltration to the base of the snow drift during the 2003 ablation season. Approximately $9 \mathrm{~m}$ downslope, an $8 \mathrm{~m}$ long plywood surface flow collector was installed across the hillslope to a depth of less than $0.05 \mathrm{~m}$, to divert any surface flow occurring within its catchment area to a gauge containing a tipping bucket mechanism. Both this tipping bucket, and the one used in the percolation lysimeter, were connected to a Campbell Scientific CR10X data logger, which recorded the number of tips every 30 minutes. Discharge for Granger Creek was calculated on a 15-minute interval using a stage-discharge relationship, with stage data provided by a stilling well with a float connected to an electronic logger. A stable stage-discharge relationship has existed for this catchment since 1998.

\section{Results and discussion}

\section{FIELD OBSERVATIONS AND IDENTIFICATION OF MAJOR PROCESSES FOR SIMULATION}

\section{Meltwater input}

The rate of meltwater release from the snowdrift must be represented in any simulation of hillslope runoff, given its position at the top of the hillslope (Fig. 1) and its large water equivalent storage. In 2002, the snow drift began melting on 30 April. At this time the drift contained a total water equivalent volume of $10820 \mathrm{~m}^{3}$, corresponding to an average water equivalent depth of $485 \mathrm{~mm}$. The drift covered $22000 \mathrm{~m}^{2}$ at the onset of melt and, after the final snow fall (14 May), the area of the drift reduced linearly with time at 
an average rate of c. $670 \mathrm{~m}^{2} \mathrm{~d}^{-1}$ (Fig. 2a) until it disappeared by c. 17 June. The snow survey and snow melt lysimeter data provided similar accounts of the pattern of meltwater release from the drift (Fig. 2b). As the lysimeters were buried in the middle of the drift where the snow depth was greatest, the lysimeter-based record of melt water release began after the record based on the snow surveys. Prior to 19 May, melt was restricted to the relatively shallow edges of the drift, as snow temperature measurements in the snow pits indicated that the deeper snow occupying the middle of the drift had not yet ripened. The amount of melt that occurred during the two-week period between initiation of the two curves
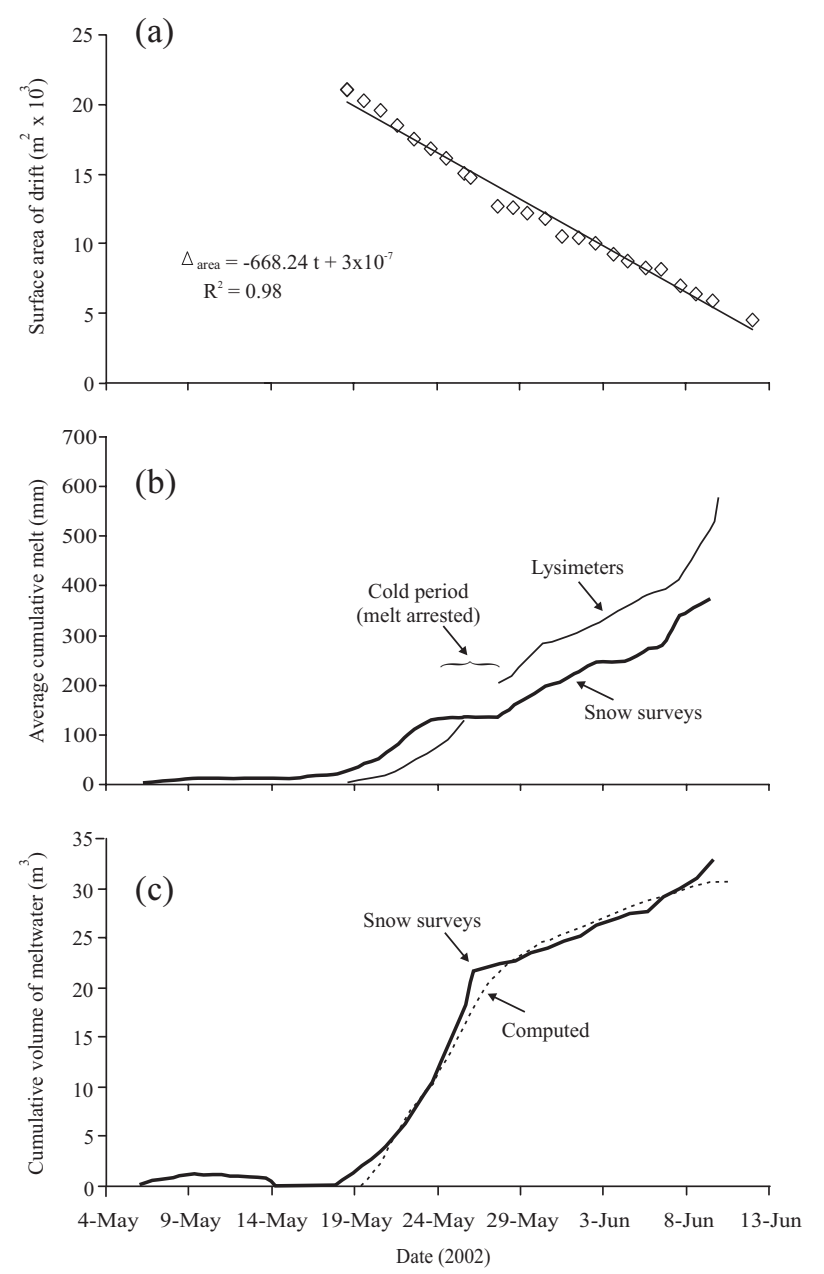

Fig. 2. (a) The variation in the surface area of the snow drift during the ablation period in 2002. (b) The cumulative melt of the snow drift computed from the daily snow depth and density measurements along the snow survey transects, and from the daily measured volumes of meltwater percolate that collected in the lysimeters. The cumulative values presented represent averages of the three snow survey transects and three melt lysimeters. (c) The cumulative volume $\left(\mathrm{m}^{3}\right)$ of melt water released from a $1-m$ wide strip through the drift (HRU 1) plotted with an estimate computed from the daily variation in measured water equivalent depths along the snow transects. was minimal, accounting for $5 \%$ of total melt calculated from the snow survey data for the entire measurement period. The snow survey measurements were used to derive the cumulative meltwater flux for the one-metre wide HRU, representing the snow drift depicted in Fig. 1 (Fig. 2c). These measurements suggest that $32 \mathrm{~m}^{3}$ was released from the snow drift HRU over a 21-day period.

The melt measurements depicted in Fig. 2 give no indication of the pattern of meltwater release within a daily period. In 2003, however, a percolation lysimeter located near the downslope edge of the drift, below $0.55 \mathrm{~m}$ of snow (72 $\mathrm{mm}$ water equivalent), indicated that meltwater was delivered to the base of the snowpack in diurnal waves. At this measurement point, the water equivalent above the lysimeter was delivered to the ground surface in five consecutive daily waves whose timing followed closely the daily cycle of net all-wave radiation measured over the snow surface (Fig. 3).

\section{Saturated layer development}

The thickness and position of the saturated layer in the soil must be represented in a simulation of hillslope runoff, since this information is needed to derive the saturated crosssectional area, hydraulic gradient, and the proportion of the saturated layer occupied by the organic and mineral soil layers. The depth of the saturated layer is also needed to compute the hydraulic conductivity, which is known to vary as a function of depth below the ground surface. During soil thawing, the frost table (zero degree isotherm) occurs at the top of the frozen saturated layer. Because this layer is relatively impermeable, the frost table is assumed to represent the lower boundary of the thawed (i.e. liquid) saturated layer, through which subsurface runoff is conducted. Over distances of a few metres, the spatial variation in the depth of soil thaw is relatively high, with maximum depths often twice that of the minimum. This local variation in thaw depth is largely controlled by local variations in soil moisture, and therefore thermal conductance; as well as by local variations in the surface energy balance (Pomeroy et al., 2003). Thaw depth was also found to vary with slope position, and field observations suggest that this is controlled by spatial variations in duration of the snow cover. For example, Fig. 4 indicates that the depth of thaw was greater at the measurement points within $10 \mathrm{~m}$ of the snow drift where the snow pack disappeared on 9 May, than at the remaining points $(45 \mathrm{~m}, 48 \mathrm{~m}, 54 \mathrm{~m}$ downslope of the drift) where the snow cover persisted until 22 May.

Because frost table depth measurements lasted only until mid-June, Fig. 4 also includes the frost table depth derived from the position of the zero degree isotherm at the 


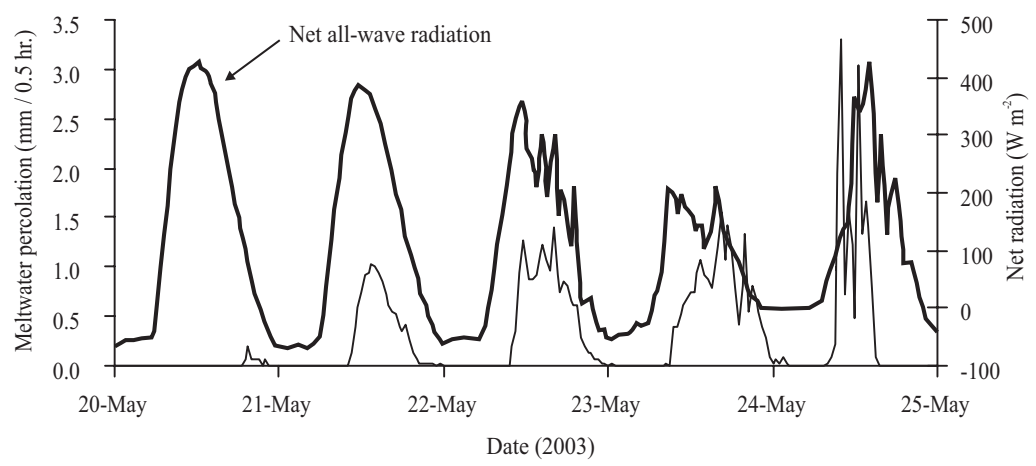

Fig. 3. Variation in the net all-wave radiation measured at the surface of the snowdrift and the meltwater percolation reaching the base of the melting snow drift in 2003.

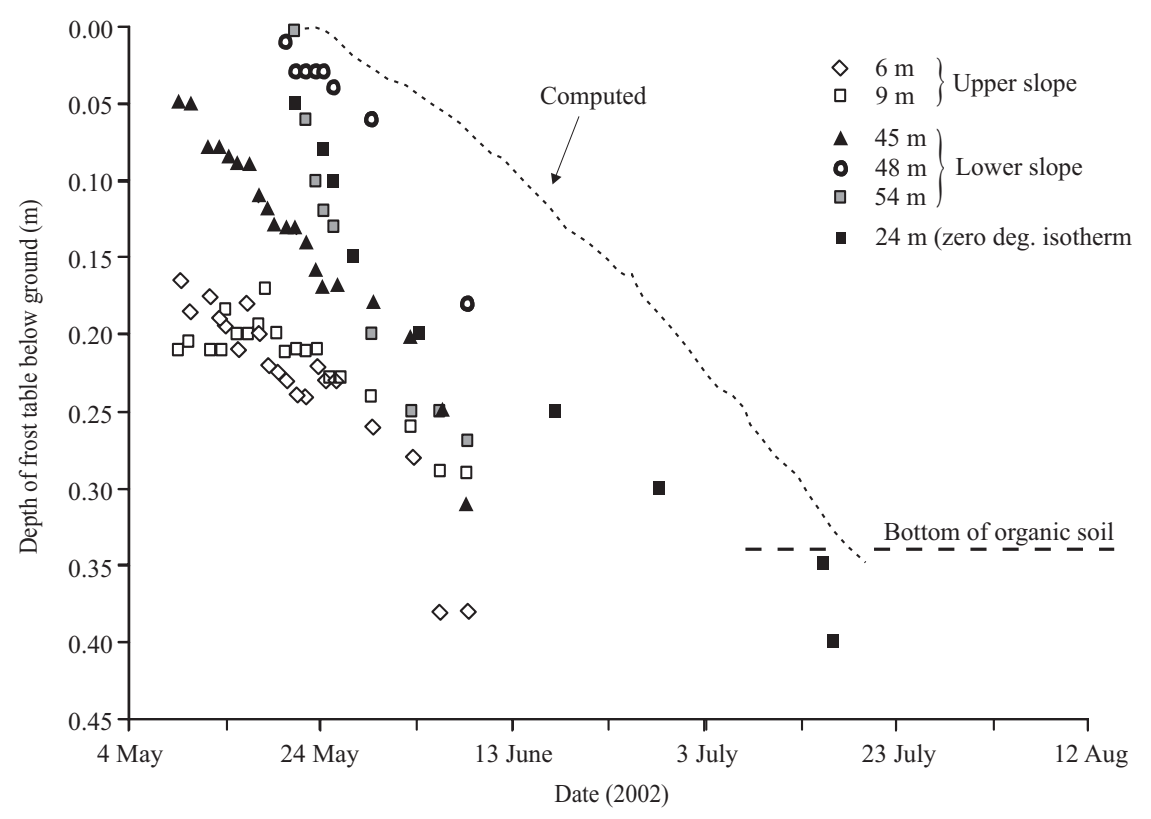

Fig. 4. Depth to the relatively impermeable frost table measured with a graduated steel rod at 6, 9, 45, 48 and $54 \mathrm{~m}$ downslope of the snow drift. The frost table position was also determined from the position of the $0^{\circ} \mathrm{C}$ isotherm at the soil pit located $24 \mathrm{~m}$ downslope of the snowdrift. The computed frost table position (dashed line) is also shown.

instrumented soil pit. These temperature-based data indicate that the frost table fell below the organic soil layer by about 8 July. The average rate of active layer thaw among the six measurement locations in Fig. 4 is $7.7 \mathrm{~mm} \mathrm{~d}^{-1}$, with rates ranging between 2.7 to $12.4 \mathrm{~mm} \mathrm{~d}^{-1}$.

The water table at the soil pit fluctuated on a daily cycle for a brief period at the beginning of the record (20-23 May), in response to the daily waves of meltwater release from the drift upslope (Fig. 5). This is followed by a period of about seven days (23-29 May) when the water table was at the ground surface, and consequently water table fluctuations in the soil were not registered. The frost table position based on the zero degree isotherm (Fig. 4) is incorporated into Fig. 5 so that the upper (water table) and lower (frost table) surfaces of the thawed (i.e. liquid) saturated layer at the soil pit are identified. The thickness of this layer increased with time, since the thaw process displaced it downward where the resistance to flow is greater.

\section{Runoff}

No overland flow was observed at the surface flow collectors, nor was surface runoff observed anywhere on the hillslope in any of the study years, not even along the downslope edge of the melting drift where the meltwater supply was high and the relatively impermeable frost table was close to the ground surface. The simulation of hillslope 


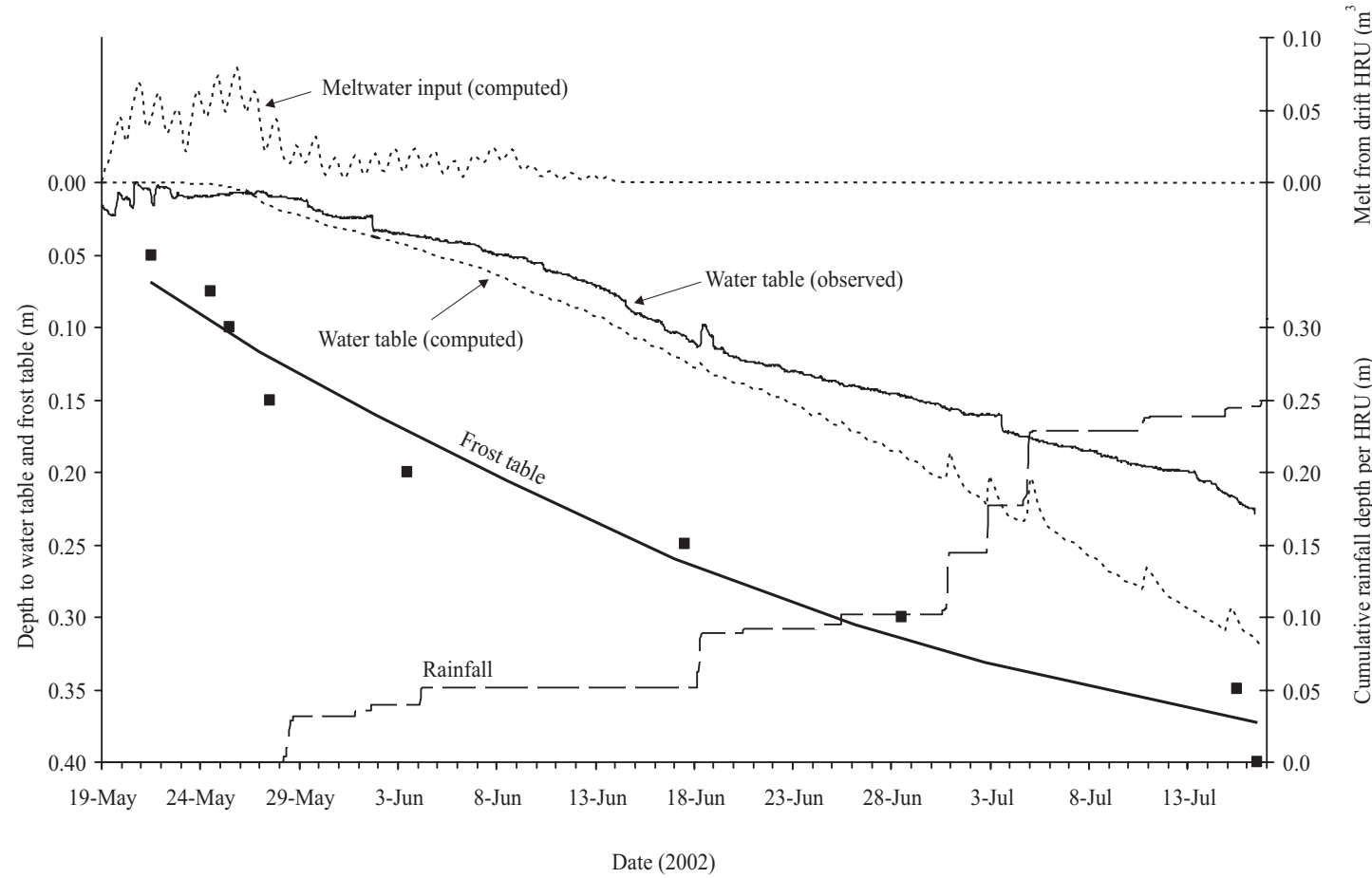

Fig. 5. The computed meltwater input from the drift during the spring melt period of 2002 is plotted with the water table fluctuation computed for HRU 3, the equivalent slope position of the soil pit. The measured variation in the depth of the water table below the ground surface at the soil pit in 2002 is plotted for comparison. The lower boundary of the thawed saturated layer is represented by the solid line plotted through the data points that indicate the position of the $0^{\circ} \mathrm{C}$ isotherm at the soil pit. The cumulative rainfall is also plotted.

runoff can therefore focus exclusively on subsurface pathways. A first step is to define the water transmission properties of the organic soil as a function of depth below the ground surface, so that an appropriate value of the hydraulic conductivity can be assigned for a given position of the saturated layer. Tracer tests demonstrated that within the $5 \mathrm{~m} \times 5 \mathrm{~m}$ study plot, the average horizontal hydraulic conductivity $(k)$ of the saturated layer fell by three orders of magnitude from $142.6 \mathrm{~m} \mathrm{~d}^{-1}$ in early June when the average depth to the middle of the saturated layer was $0.14 \mathrm{~m}$, to $0.9 \mathrm{~m} \mathrm{~d}^{-1}$ in September when this average depth was $0.3 \mathrm{~m}$. Although $k$ varied spatially by two orders of magnitude in early June, by September this variation reduced dramatically to fall within the range of 0.58 to $1.24 \mathrm{~m} \mathrm{~d}^{-1}$ (Fig. 6).

Pore velocities computed from the tracer tests reduced from an average value of $40.4 \mathrm{~m} \mathrm{~d}^{-1}\left(\sigma=57.1 \mathrm{~m} \mathrm{~d}^{-1}, \mathrm{~N}=7\right)$ in the June experiment to $0.38 \mathrm{~m} \mathrm{~d}^{-1}\left(\sigma=0.09 \mathrm{~m} \mathrm{~d}^{-1}, \mathrm{~N}=8\right)$ in September, 2000. Two of the seven pore velocity observations in June exceeded $100 \mathrm{~m} \mathrm{~d}^{-1}$ confirming that daily melt water waves introduced to the top of this hillslope can be conveyed through all seven tundra HRUs (i.e. HRUs 2-8) and enter the stream channel within a diurnal cycle. These measured pore velocities indicate that the transit time

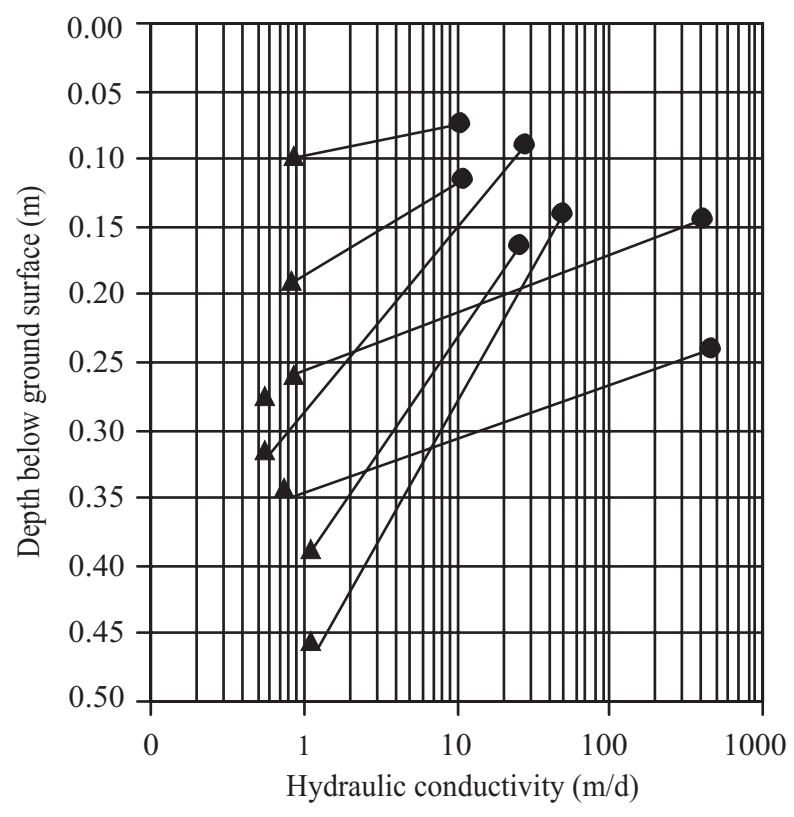

Fig. 6. Hydraulic conductivity ( $k$ ) computed from tracer tests conducted on 3 June (circles) and 13 September (triangles), 2000. The sensors were left in the same location for both tests hence, for each point, the two tests provide an estimate of the range of $k$ over the intervening period while the saturated layer was at some intermediate position. 
through each $10 \mathrm{~m}$ HRU ranged between an average of $0.25 \mathrm{~d}$ early in June to over $26 \mathrm{~d}$ in September.

To check the accuracy of the pore velocities computed from the tracer tests, a second estimate was obtained using the field data from June, 2000. For rain-free days, and after the drift ripened to $0^{\circ} \mathrm{C}$ throughout its depth, the daily fluctuation of net all-wave radiation was used to indicate the variation in the rate of melt water discharge from the drift. The subsurface flow velocity between the snow drift and the well (well 1) was estimated by dividing the time difference between the peak of the radiation (Fig. 7a) and water level (Fig. 7b) curves by the distance between the downslope edge of the drift and the well. This analysis was conducted for the period 7-30 June, 2000 during which time
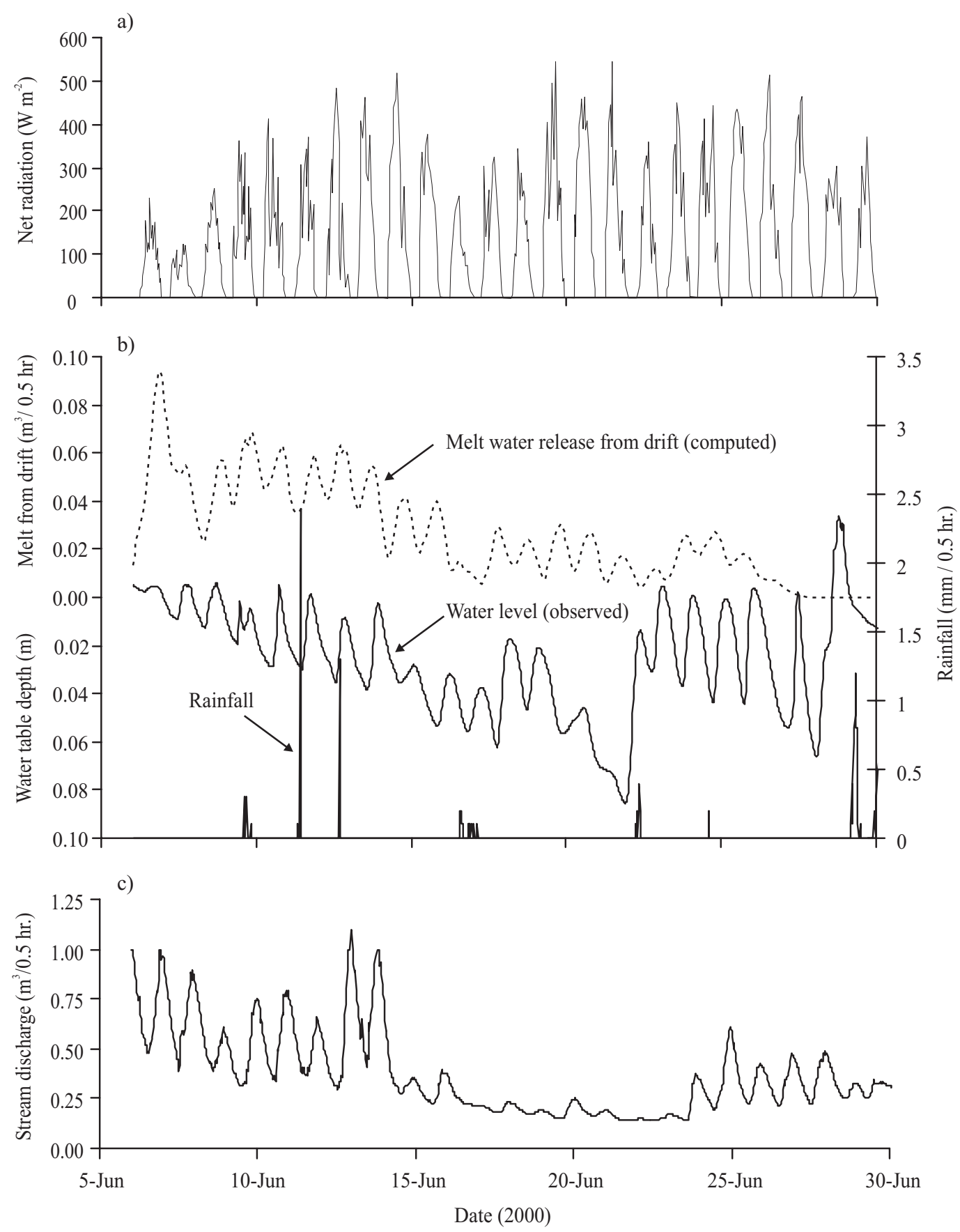

Fig. 7. Variation in (a) measured net all-wave radiation measured above the ablating snowdrift, (b) the computed melt water release from the snow drift and the computed water table response down slope of this drift, and (c) measured discharge from the stream channel at the bottom of the hillslope in 2000. 
the melting snow drift receded from $5 \mathrm{~m}$ to $17.5 \mathrm{~m}$ upslope of the well. Accounting for this increase in flow distance, the difference in timing of the radiation and water level curve peaks, suggests an average flow velocity of $33.2 \mathrm{~m} \mathrm{~d}^{-1}$ $\left(\sigma=16.6 \mathrm{~m} \mathrm{~d}^{-1}, \mathrm{~N}=17\right)$, which is reasonably close the average value obtained from the tracer test $\left(40.4 \mathrm{~m} \mathrm{~d}^{-1}\right)$ in the same period. The same analysis was performed for the following two spring melt periods, for which the average flow velocity was $33.5 \mathrm{~m} \mathrm{~d}^{-1}\left(\sigma=16.8 \mathrm{~m} \mathrm{~d}^{-1}, \mathrm{~N}=34\right)$ in 2001 and $28.9 \mathrm{~m} \mathrm{~d}^{-1}$ $\left(\sigma=7.4 \mathrm{~m} \mathrm{~d}^{-1}, \mathrm{~N}=29\right)$ in 2002 .

Although the average velocities estimated for 2000, 2001 and 2002 indicate that it takes over two days for water released from the drift to reach the stream bank; maximum velocities estimated from this approach in 2000 and 2001 exceeded $80 \mathrm{~m} \mathrm{~d}^{-1}$, indicating that the melt water released from the drift could reach the stream within a day. Considering these high velocities, and the occurrence of the minimum velocities of between 15 and $20 \mathrm{~m} \mathrm{~d}^{-1}$ in each year, the mixing of daily drainage waves of different velocities over the slope seems possible. However, the fact that daily flow pulses were observed in the stream channel (Fig. 7c) and from the snow drift at the top of the hillslope (e.g. Fig. 3), suggests that a cycle of individual daily meltwater waves was conducted through the intervening hillslope.

\section{PROCESS SIMULATION}

To diagnose the conceptual understanding of the major processes identified above, and to identify any shortcomings, a numerical runoff simulation model was constructed from mathematical representations of these processes. The model was designed to handle a one metre wide strip normal to a stream channel, composed of HRUs (Fig. 1) whose properties are determined by the parameters assigned to them based on field measurements. All computations were made on a 30-minute time step. For each step, three input variables were used: temperature of the ground surface $(T S)$, air temperature $(T a)$ and rainfall $(P)$. In addition, the following physical parameters were defined: initial mean snow water equivalent of the HRU occupied by the snow drift (HRU 1), degree day melt factor for the melt of the drift, and the initial position of the top of the frozen saturated layer prior to melt. The organic soil was assigned a thickness of $0.35 \mathrm{~m}$, and was divided into three layers (Fig. 1): a $0.15 \mathrm{~m}$ upper layer overlying two $0.1 \mathrm{~m}$ thick layers. It was assumed that these layers resided above mineral sediment. For each soil layer, the model requires that the thermal and physical properties discussed below are defined, as is the slope gradient of each HRU.

\section{Meltwater input}

Snowmelt was computed from a degree-day air temperature approach (Dingman, 2002), instead of a more rigorous energy-balance approach, to limit the uncertainty in model output to errors in the representation of the subsurface thaw and drainage processes. Future evolution of the model will require that other major processes including snowmelt, percolation through snow and streamflow be represented physically.

In the present model, the snow comprising the drift was assumed to be distributed over the length of the drift HRU (HRU 1), approximately as a right angle triangle, since the snow depth is greatest in the middle of a drift and least at its edges. The altitude of this triangle is twice the initial mean snow water equivalent and its base is the HRU length. As the snow melts, the triangle keeps the same proportions with all the melt occurring on the down-slope edge. This assumption is consistent with the observed linear pattern of ablation (Fig. 2a). It was also assumed that during ablation, the snow-covered area of the drift remained intact while shrinking (Erickson et al., 1978).

\section{Saturated layer development}

It is assumed that heat flows into the soil mainly by conduction (Nixon, 1975; Fuchs, 1986), is one-dimensional and the medium is reasonably isotropic and homogeneous. Therefore, the energy equation is:

$$
D_{t}^{\frac{\partial^{2} T}{\partial z^{2}}}=\frac{\partial T}{\partial t}
$$

where $D_{t}$ is the thermal diffusivity, equal to $k_{T} / C_{v}$ (in which $\mathrm{k}_{\mathrm{T}}$ is the thermal conductivity; and $\mathrm{C}_{\mathrm{v}}$, is the volumetric heat capacity). $C v$ is the product of the density $(\Delta)$ and specific heat $(c)$ of the media. $\mathrm{T}$ is soil temperature, $\mathrm{z}$ is the vertical coordinate and $t$ is time. The model requires that the initial depth of the frost table, and the initial volumetric moisture content and temperature measured at the mid-point of the three soil layers of the model be defined. The porosity, bulk density, and thermal properties of these layers also need to be defined. For the unsaturated/unfrozen, saturated/frozen and saturated/unfrozen conditions (Farouki, 1981), the model computes the composite values of $C v, k_{T}$, and $D_{t}$ for each model layer, from the volumetric soil moisture $\theta_{\mathrm{m}}$, and porosity $N$ measured within each soil layer, and from the heat capacities of the water, ice, soil and air constituents, obtained from the literature (Oke, 1987). The changes in depth to the frost table were then derived on the assumption that the one-dimensional heat balance of the active layer during soil thaw is,

$$
Q_{G}=Q_{A}+Q_{P}+Q_{M}
$$


where $Q_{G}$, the heat flux into the soil, is used to warm the active layer $\left(Q_{A}\right)$ and underlying permafrost $\left(Q_{P}\right)$, and to lower the frost table by melting ice $\left(Q_{M}\right)$.

The timing and magnitude of the water table fluctuations in response to inputs (i.e. snowmelt or rainfall) and lateral drainage input of a known rate, is computed from the initial elevation of the water table, the drainable porosity of the organic material at that elevation, and the depth of water input.

\section{Flow rates}

The conservation equation describing lateral movement through the saturated substrate is

$$
\frac{\partial\left(q_{x} h\right)}{\partial x}+\phi \frac{\partial h}{\partial t}=I(x, t)
$$

where $q_{x}$ is the flow/unit area/unit time (velocity) in the downslope direction, $x, h$ is the thickness of the saturated layer, $t$ is time, and $I(x, t)$ is the net flow to the saturated layer equal to infiltration entering from above less percolation to underlying soil, a function of $x$ and $t$. Assuming Darcian flow, homogeneous material and that $I$ is constant, the governing equation for flow in the saturated layer is:

$$
\alpha K \theta \frac{\partial h}{\partial t}-\alpha K \frac{\partial\left(\frac{h \partial h}{\partial x}\right)}{\partial x}+\phi \frac{\partial h}{\partial t}=I
$$

where $\nabla=\Delta_{w} g / \mu$, (in which $\Delta_{w}$ is the density of water, $g$ is gravitational acceleration and $\mu$ is the viscosity of water), $K$ is permeability, 2 is the slope of the layer. The quantity $\forall K$ is the hydraulic conductivity, $k$.

The lateral flow is considered the primary pathway affecting water transit time from infiltration into the ground until arrival at the base of hillslope, as the vertical transit time from the ground surface to the water table is negligible (Quinton et al., 2000). Lateral subsurface runoff from each HRU was computed from the HRU slope, and the transmission properties of the soils in the saturated layer. The Darcy-Weisback expression was used to define the permeability $K$ of the saturated layer as $K=2 D^{2} / C$, where $D$ is the geometric mean pore diameter in this layer, and $C$ is a coefficient. The linear relationship between $C$ and the depth to the middle of the saturated zone, $d$ reported by Quinton and Gray (2001) was used to estimate the variation in $K$ with depth from estimates of the variation in geometric mean pore diameter $(D)$ obtained from laboratory analysis of the soil cores. From the soil permeability $K$, the hydraulic conductivity $(k)$ was derived from $k=\alpha K$. The subsurface drainage water was routed downslope from HRU to HRU using the lag and route method (Clark, 1945) that calculates the outflow from each HRU.

\section{COMPARISON OF SIMULATED AND OBSERVED} DATA

\section{Meltwater input}

The snowmelt computations indicate that melt commenced on 19 May (Fig. 2c). Since this date corresponds with the date when the initial pulse of melt water percolate was measured in the lysimeters in the centre and deepest part of the drift (Fig. 2b), the computed melt curve represents the period when the entire cross-section of the drift was melting. The relatively small amounts of melt measured by the daily snow surveys prior to 19 May (Fig. 2c) were not detected by the index method and likely represent melt at the relatively shallow edges of the drift. Fig. 2c also indicates that the timing and magnitude of the computed cumulative release of melt water closely matched the measured cumulative curve (snow surveys) for the one-metre wide drift HRU. The computed pattern of melt per 0.5 hour time step (Fig. 5) indicates that snowmelt was released from the drift HRU in daily waves, consistent with field observations in the 2003 melt period (Fig. 3).

\section{Saturated layer development}

The model estimated that the active layer thawed at an average rate of $5.7 \mathrm{~mm} \mathrm{~d}^{-1}$, slightly lower than the average measured rate of $\left(7.7 \mathrm{~mm} \mathrm{~d}^{-1}\right)$ but within the measured range ( 2.7 to $12.4 \mathrm{~mm} \mathrm{~d}^{-1}$ ). However, Fig. 4 indicates that despite the similarity in the slopes of the measured and computed data, they intercept the vertical axis over a range of more than $0.2 \mathrm{~m}$, reflecting a large spatial variation in active layer thaw. Field observation suggests that this results from the variation in the time when the ground becomes snow-free and is able to begin thawing. The thaw computation commenced on 19 May, once the ground below the infrared sensor at the meteorological tower became snow-free, enabling $T s$ to rise above $0^{\circ} \mathrm{C}$. However, by this time the area downslope of the drift represented by HRUs 2-8, was approximately $50 \%$ snow-free, and in some areas of the hillslope the frost table depth was already $>0.2 \mathrm{~m}$ (Fig. 4). The present method of computation therefore appears to give reasonable results for active layer thaw at a point, but is unable to capture the relatively large variability of thaw over the slope. In the present case, where the ground below the meteorological tower became snow-free relatively late, soil thaw began later in the model simulation than what was observed at many points (Fig. 4).

The model did not allow the water table to fall below the ground surface until 24 May, since the simulated frost table elevation remained at the ground surface until that date (Fig. 
4). Model estimates of the water table elevation in each HRU suggest that the variation in water table depth between the upper (HRU 2) and lower (HRU 8) regions of the hillslope was minimal while the snow drift was present, and that substantial variations in water table depth did not develop until mid-June, after the drift had disappeared and the frequency of rainfall increased (e.g. Fig. 5).

\section{Flow rates}

The large meltwater supply and limited soil thaw of the spring melt period was expected to produce a large volume and rate of water delivery from the hillslope. For the three study seasons from 2000 to 2002 , although the melting snow drift was present for only the initial $24 \%$ of the time period between the start of snowmelt runoff and 1 September, the computed cumulative hillslope runoff of this initial period was on average $59 \%$ of the cumulative value for the entire period of computation ending on 1 September in each year. The computed rate of melt water release from the drift is plotted with the resulting subsurface drainage from the HRUs at the top (HRU 2) and bottom (HRU 8) of the hillslope in Fig. 8a for 2002. The $2.75 \mathrm{~d}$ time delay between the computed discharge peaks of HRU 2 (27 May at 02:00) and HRU 8 (29 May at 20:00), suggests that water was translated through the $70 \mathrm{~m}$ hillslope at an average rate of $25.5 \mathrm{~m} \mathrm{~d}^{-1}$. This compares closely with the average subsurface runoff velocity derived from the analysis of the radiation and water level curves $\left(28.9 \mathrm{~m} \mathrm{~d}^{-1}\right)$. Given that the 19 to 29 May portion of the melt period was characterized by a high level of meltwater input at the top of the hillslope (Fig. 8a) and a high stage level measured in the stream channel at the bottom of the slope (Fig. 8b), the computed high level of discharge through the intervening hillslope during this period seems reasonable.

a)

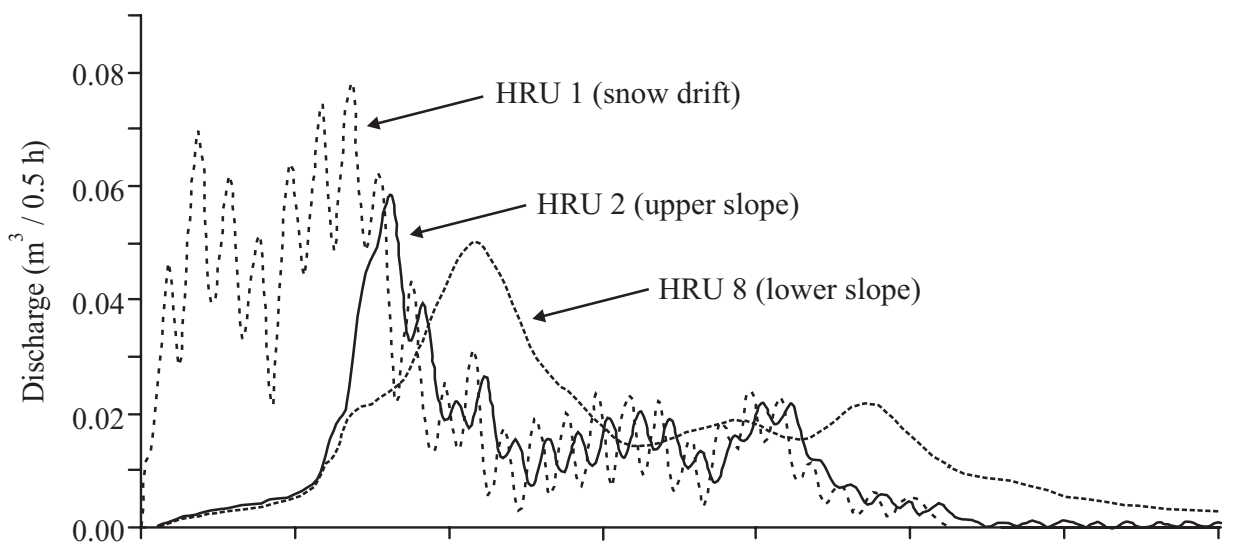

b)

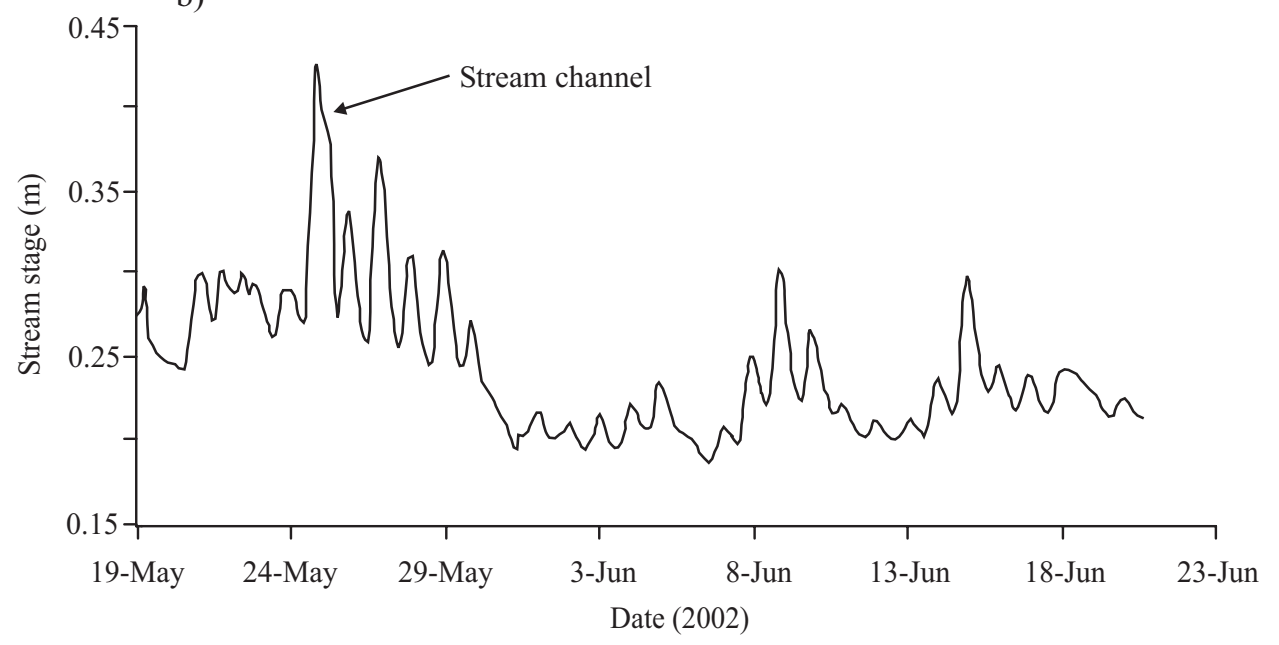

Fig. 8. (a) The computed discharge of meltwater from the snow drift (HRU 1) during the melt period of 2002, and the resulting discharge from HRU 2 at the top of the hillslope and HRU 8 at the bottom of the slope and adjacent to the stream channel. (b) The variation in stream stage over the same period. 
Figure $8 \mathrm{a}$ also indicates that the daily pulses decrease in magnitude with flow distance between HRU2 and HRU8, and are no longer discernible at the base of the hillslope. However, this model result is inconsistent with the suggestion that the daily pulsing of subsurface drainage is preserved throughout the hillslope length. Additional water table monitoring was conducted in 2003 to gain insight into the manner in which the subsurface water is conveyed through the hillslope, yet the findings were inconclusive, as pronounced diurnal pulsing such as shown in Fig. 7b was observed in some areas, while in other areas such as the soil pit (Fig. 5), very little pulsing occurred. This seems to suggest the presence of preferential pathways and other variable drainage mechanisms operating at different positions on the slope, as reported by other studies in similar environments (e.g. Hinzman et al., 1993; Carey and Woo, 2000b).

Figure 8a shows that despite the high melt water input rates commencing 19 May, 2002, the computed subsurface discharge remained at a low level until approximately 25 May. Throughout most of the intervening period, the relatively impermeable frost table was computed to be within $10 \mathrm{~mm}$ of the ground surface (Fig. 4), and the appreciable meltwater input that could not be accommodated through this meagre thawed layer was therefore assumed to have drained over the ground surface. After 25 May, the computed frost table was sufficiently deep to accommodate all meltwater through the thawed zone, and overland flow was therefore no longer predicted in the runoff simulation.

Despite the relatively short period during which overland flow was predicted to occur, by 15 June, when meltwater inputs from the drift had ended (Fig. 2), overland flow was estimated to have conveyed $40 \%$ of the total meltwater from the drift. However, the fact that no overland flow was observed during the study indicates that the actual active layer development during the melt period was sufficient to accommodate all meltwater input through the subsurface. This is supported by the data presented in Fig. 4 that indicate the actual depth to the frost table was greater than computed depth, and therefore the capacity of the active layer to accommodate and conduct meltwater input was underestimated.

The absence of observed overland flow may also indicate that alternate flow mechanisms, capable of conveying rapidly a substantial portion of the snowmelt water were active. Figure 4 also illustrates a high spatial variability of soil thaw. Variations in thaw depth have important implications to spatial variations in the flow, including the seasonal development of preferential flowpaths, since it has been shown that horizontal hydraulic conductivity can decrease by one to two orders of magnitude over a $0.1 \mathrm{~m}$ increase in thaw depth (Fig. 6).

\section{Summary and conclusions}

The model simulations, field measurements and observations indicate that northern alpine tundra exhibits two seasonallycharacteristic runoff regimes. The spring regime is characterised by large input rates supplied mainly by snowmelt, a relatively small soil storage capacity, but rapid subsurface fluxes through the highly conductive living and lightly decomposed organic soil near the ground surface. Because the organic soil in this environment is relatively thin, soil thaw lowers the frost table into the underlying mineral sediment early in the summer period. Field measurements indicate that in 2002 this occurred during the first week of July (Fig. 4). This process displaces the liquid saturated layer into deeper organic material and mineral sediment where the hydraulic conductivity is two or more orders of magnitude lower than it is near the ground surface (Fig. 6). The summer regime is therefore characterised by low flow rates, a lower input rate that is supplied mainly by rainfall and an increased soil storage capacity.

The focus of this study was on the spring regime. The model simulations for 2000, 2001 and 2002 indicate the importance of this regime hydrologically, since they show that the majority ( $59 \%$ ) of the cumulative hillslope drainage from the onset of runoff in the spring until 1 September occurred during the initial 3-4 week period. For the spring regime, the major processes to be represented in a runoff model include the rate of meltwater release from the latelying snowdrift, the elevation and thickness of the saturated layer, the magnitude of the soil permeability and its variation with depth. It was found that during ablation, the surface area of the drift decreased linearly with time. This is important from a modelling point of view since it provides a basis for estimating the reduction in the runoff source area with time during the spring regime. Field measurements also suggest that the daily cycle of net all-wave radiation drives the diurnal pulses of melt water release from the drift, which controls the daily pulses of subsurface drainage from the hillslope, and ultimately the daily pulses in the stream channel as well. These daily fluctuations throughout the flow system, from the snowpack to the stream channel, characterise the spring runoff regime in this environment.

An obvious weakness of the model concerns the extrapolation from conditions observed at a point (e.g. soil pit or meteorological tower) to the entire hillslope. This is especially true of the soil thaw simulation, given the large observed spatial variability in frost table depth (Fig. 4). The underestimation of soil thaw by the model led it to 
erroneously predict large volumes of overland flow, when none was observed. Future simulations of hillslope runoff in alpine tundra environments will need to represent thaw variability. This will first require field investigations aimed specifically at improving the understanding of the distribution of energy used to melt snow and thaw the snowfree ground during the ablation season.

Preferential thaw leads to the development of preferential flowpaths, which this study indicates play a very important role during the spring runoff regime. From the model simulations and field measurements, an understanding of the seasonal evolution of preferential flowpaths has begun to develop. Generally, preferential flow occurs in areas of the hillslope that (1) have relatively high soil thaw, and (2) receive drainage from surrounding areas (e.g. topographic lows, areas downslope of melting snow). Spatial variations in soil thermal properties and surface energy balance produce spatial variations in thaw depth. This generates local slopes in the frost table causing water to flow toward areas of greater thaw depth. Water may refreeze during this process leading to the release of latent heat and additional thawing. Water near the frost table moves more slowly in areas of greater thaw depth, due to the decrease in hydraulic conductivity with depth. Therefore, if water continues to flow toward these areas of greater thaw, and if the flux of water from these areas is lower than the flux of water to them, they will accumulate water. As their saturated layer thickens, the water table will rise toward the ground surface, and flow from areas of greater thaw will increase due to an increase in hydraulic conductivity and hydraulic head gradient.

\section{Acknowledgements}

The authors gratefully acknowledge the logistical support of the Department of Indian and Northern Affairs, particularly through the efforts of Glen Ford and Richard Janowicz. They would also like to thank Dr. Raoul Granger and Newell Hedstrom for their logistical support in the field, and for the use of their field equipment. They also wish to thank Chris deBeer and Steve MacCartney for their assistance in the field. The Natural Sciences and Engineering Research Council (NSERC), the Canadian Foundation for Climate and Atmospheric Sciences (CFCAS), and the Yukon Territorial Government provided funding for this project. They also gratefully acknowledge Mr. Tom Brown for his assistance in developing the model code, Dr. D.M. Gray for his helpful insights during this study and the anonymous referees for their helpful comments.

\section{References}

Abbey, F.L., Gray, D.M., Male, D.H. and Erickson, D.E.L., 1978. Index models for predicting heat flux to permafrost during thawing conditions. In: Proc. Third Int. Permafrost Conf., National Research Council of Canada, Ottawa, Canada. vol. 1, 3-9.

Bliss, L.C. and Matveyeva, N.V., 1992. Circumpolar Arctic Vegetation. In: Arctic Ecosystems in a Changing Climate: An Ecological Perspective, F.S. Chapin III, R.L.Jefferies, J.F. Reynolds, G.R. Shaver and J. Svoboda (Eds.), Academic Press, San Diego, USA. 59-89.

Carey, S.K. and Woo, M.-K., 2000a. Within slope variability of ground heat flux, Subarctic Yukon. Phys. Geogr., 21, 407-417.

Carey S.K. and Woo, M.-K., 2000b. The role of soil pipes as a slope runoff mechanism, subarctic Yukon, Canada. J. Hydrol., 223, 206-222.

Carey, S.K. and Woo, M.-K., 2001. Slope runoff processes and flow generation in a subarctic, subalpine environment. $J$. Hydrol., 253, 110-129.

Chacho, E.F. and Bredthauer, S., 1983. Runoff from a Small Subarctic Watershed, Alaska. Proc. Fourth Int. Permafrost Conf., Fairbanks, Alaska. 115-120.

Clark, C.O., 1945. Storage and the unit hydrograph. Proc. Amer. Soc. Civil Eng., 69, 1419-1447.

Dingman, S.L., 1973. Effects of Permafrost on Streamflow Characteristics in the Discontinuous Permafrost Zone of Central Alaska. In: Permafrost: the North American contribution to the Second International Conference, Yakutsk, U.S.S.R. Washington, National Academy of Sciences, 447-453.

Dingman, S.L., 2002. Physical Hydrology, $2^{\text {nd }}$ Edition. Prentice Hall, New Jersey, USA. 646pp.

Erickson, D.E.L., Lin, W. and Steppuhn, H.W., 1978. Indices for estimating Prairie runoff from snowmelt. 7th Symposium on Applied Prairie Hydrology. Water Studies Institute, Saskatoon, Sask., Canada.

Essery, R.L.H., Li, L. and Pomeroy, J.W., 1999. A distributed model of blowing snow over complex terrain. Hydrol. Process., 13, 2423-2438.

Farouki, O.T., 1981 The thermal properties of soils in cold regions. Cold Regions Sci. Technol., 5, 61-65.

Fuchs, M., 1986. Heat flux. In: Methods of Soil Analysis, Part 1, Physical and Mineralogical Methods (second edn), A. Klute (Ed.), Soil Sci. Soc. Am., Madison, Wisconsin, USA. 957-968.

Hinkel, K.M. and Nicholas, J.R.J., 1995. Active layer thaw rate at a boreal forest site in central Alaska. USA. Arctic Alpine Res., $27,72-80$.

Hinzmann, L.D., Kane D.L. and Everett, K.R., 1993. Hillslope Hydrology in an Arctic Setting. Proc. Sixth Int. Permafrost Conf. July 5-9, Beijing, China. Vol. 1.

Lewkowicz, A.G. and. Young, K.L, 1990. Hydrological processes in a small catchement containing a perennial snowbank, Melville Island, N.W.T. In: Northern Hydrology, Selected Perspectives, T. Prowse and C.S.L. Ommanney (Eds.). NHRI Symposium No. 6, 237-251.

Marsh, P. and Woo, M.-K., 1981. Snowmelt, Glacier Melt, and High Arctic Stream Flow Regimes. Can. J. Earth Sci., 18, 13801384.

Marsh, P. and Pomeroy, J.W., 1999. Spatial and temporal variations in snowmelt runoff chemistry, Northwest Territories, Canada. Water Resour. Res., 35, 1559-1567.

National Research Council of Canada (NRC), 1988. Glossary of Permafrost and Related Ground-Ice Terms, Permafrost Subcommittee, Associate Committee on Geotechnical Research. Technical Memorandum No. 142, Ottawa, Canada.

Nixon, J.F., 1975. The role of convective heat transport in the thawing of frozen soil. Can. Geotech. J., 12, 425-429. 
Oke, T.R., 1987. Boundary Layer Climates, $2^{\text {nd }} \mathrm{ed}$. Routledge, London, UK. 435pp.

Pomeroy, J.W. and Granger, R.J., 1999. Wolf Creek Research Basin: Hydrology, Ecology, Environment. National Water Research Institute, Environment Canada. 160pp.

Pomeroy, J.W., Lesack, L. and Marsh, P., 1993. Relocation of major ions in snow along the tundra-taiga ecotone. Nordic Hydrol., 24, 151-168.

Pomeroy, J.W., Marsh, P., Jones, H.G. and Davies T.D., 1995. Spatial Distribution of Snow Chemical Load at the Tundra-Taiga Transition. Biogeochemistry of Seasonmally Snow-covered Catchments. IASH publication no. 228.

Pomeroy, J.W., Toth, B., Granger, R., Hedstrom, N. and Essery, R., 2003. Variation in surface energetics during snowmelt in a subarctic mountain catchment. J. Hydrometeorol., 4, 702-719.

Pomeroy J.W, Granger R.J, Pietroniro A., Elliot J., Toth B. and Hedstrom N.R., 1997. Hydrological Pathways in the Prince Albert Model Forest. NHRI Contribution Series No. CS-97004. National Hydrology Research Institute, Environment Canada: Saskatoon. 154pp.

Quinton, W.L. and Gray, D.M., 2001. Toward modelling seasonal thaw and subsurface runoff in arctic tundra environments. Soil Vegetation, atmosphere transfer (SVAT) schemes and large scale hydrological models. IAHS publication no. 270, 333-341.

Quinton W.L. and Gray, D.M., 2003. Subsurface drainage from organic soils in permafrost terrain: the major factors to be represented in a runoff model. Proc. 8th Int. Conf. on Permafrost, Davos, Switzerland. 6pp.

Quinton, W.L. and Marsh, P., 1998. Melt water fluxes, hillslope runoff and stream flow in an Arctic permafrost basin. Permafrost - 7th Int. Conf., Yellowknife, Canada, A.G. Lewkowicz and M. Allard (Eds.). Laval University Press. 921-926.

Quinton, W.L. and Marsh, P., 1999. A Conceptual Framework for Runoff Generation in a Permafrost Environment. Hydrol. Process., 13, 2563-2581.
Quinton, W.L., Gray, D.M. and Marsh, P., 2000. Subsurface Drainage from Hummock- Covered Hillslopes in the ArcticTundra. J. Hydrol., 237, 113-125.

Roulet, N.T. and Woo, M.-K., 1988. Runoff generation in a low arctic drainage basin. J.Hydrol., 101, 213-226.

Slaughter, C.W. and Kane, D.L., 1979. Hydrologic Role of Shallow Organic Soils in Cold Climates. Proc. Canadian Hydrology Symposium: Cold Climate Hydrology, 10-11 May, 1979, Vancouver, B.C.

Sturm, M., Morris, K. and Massom, R., 1998. The winter snow cover of the West Antarctic pack ice: its spatial and temporal variability. In :Antarctic Sea Ice - Antarctic Research Series 74 M.O. Jeffries (Ed.), American Geophysical Union: Washington, D.C. USA. 1-18.

Verry, E.S. and Boelter, D.H., 1978. Peatland hydrology. In: Wetland Functions and Values: The State of Our Understanding, P. Greeson (Ed.), Proc. National Symp. on Wetlands. Lake Buena Vista, Florida, Nov. 7-10. Minneapolis, MN., American Water Res. Assoc. 389-402.

Woo, M.-K. and Steer, P., 1983. Slope hydrology as influenced by thawing of the active layer, Resolute, N.W.T. Can. J. Earth Sci., 20, 978-986.

Woo, M.-K and Xia, Z., 1994. Effects of hydrology on the thermal conditions of the active layer: hydrological processes and runoff at the Arctic treeline in Northern Canada. In: Proc. Tenth Int. Northern Research Basins Symp. and Workshop (Svalbard, Norway), K. Sand and A. Killingtveit (Eds.), 429-448.

Zhao, L. and Gray, D.M., 1999. Estimating snowmelt infiltration into frozen soils. Hydrol. Process., 13, 1827-1842. 